
\title{
25 Research Soure \\ Using A Novel Continuous Bioreactor In Enhancing The Biogas Production
}

\section{Mohammad Amui Khorshidi}

Quchan University of Technology

Hossein Beiki ( $\boldsymbol{Q}$ hbeiki@qiet.ac.ir)

Quchan University of Technology https://orcid.org/0000-0002-1271-3935

\section{Mojtaba Kanvisi}

Quchan University of Technology

\section{Research}

Keywords: Biogas, Continuous Bio-Reactor, Methane, Sugar Beet Waste

Posted Date: May 17th, 2021

DOI: https://doi.org/10.21203/rs.3.rs-509731/v1

License: (1) This work is licensed under a Creative Commons Attribution 4.0 International License. Read Full License

Version of Record: A version of this preprint was published at Biomass Conversion and Biorefinery on February 14th, 2022. See the published version at https://doi.org/10.1007/s13399-022-02445-w. 


\section{Abstract}

Background: Since fossil fuels are limited and their burning is considered the main reason for environmental pollution, thinkers in the energy section are looking for a substitute for them. They have considered biogas as a potent replacement. Constant composition and volumetric rate, are ones of the challenges faced in term of using biogas. Therefore, in this study, a novel easily portable continuous bioreactor was designed and constructed to produce biogas at constant composition and volumetric rate, which is suitable for human uses. Sugar beet waste and anaerobic sludge were used as substrate and inoculum with an $\mathrm{S} / \mathrm{I}$ ratio of 0.5 to 1 , to produce biogas. Four parameters, i.e., hydraulic retention time (HRT), pH, biogas volume, and methane composition, were measured and compared.

Results: The results of the mentioned reactor were compared with those of batch ones. The measurement revealed that the continuous reactor had a good performance on biogas purity and volumetric rate. The biogas contained about $53 \%$ methane. The suitable and preferable HRT and organic loading rate (OLR) were 18 days and $34.86 \mathrm{~g} \mathrm{VS/day.} \mathrm{After} \mathrm{the} \mathrm{18th} \mathrm{day} \mathrm{of} \mathrm{operation,} \mathrm{the} \mathrm{biogas} \mathrm{production} \mathrm{process} \mathrm{inside}$ the continuous reactor was stable reaching about $411.2 \mathrm{ml} \mathrm{STD/g}$ VS per day.

Conclusions: The reactor designed makes the biogas production process more manageable. Besides the production of the cumulative volume of biogas and constant methane percentage was achieved. As a result, the biogas produced is consumed daily, and a certain amount of gas is available every day. Since the percentage of gas produced is constant, it is possible to adjust the gas appliances with this amount of methane.

\section{Background}

In recent years, various studies have been conducted on the use of new fuels and renewable energy [1-8]. One of the oldest methods of renewable energy production is the conversion of biomass to biogas; the method which, in addition to producing heat and electrical energy from, have other advantages, like nutrient-rich digestate as biofertilizer, and reduced volume of weed seeds and its smell [9]. Anaerobic digestion systems use sewage sludge, animal manure and organic wastes feed to produce biogas. In countries where biogas production is less developed, animal manure is used as a rich source of microorganisms [10]. These systems draw very much attention due to low cost and energy requirements for start-up and maintaining the process, as well as low sludge production [11].

One of the biggest environmental problems which the world grapples with its greenhouse gas emissions such as $\mathrm{CO}_{2}, \mathrm{CO}, \mathrm{CH}_{4}$, and $\mathrm{NO}_{\mathrm{x}}$. Using fossil fuels contributes to the production of these gases and climate change. Using biomass as a renewable energy source is an efficient way to reduce the use of fossil fuels and thereby reduce greenhouse gas emissions [12]. High-quality biogas production can be used in transportation, home, and even industrial uses like poultry farms.

Due to the importance of high-efficiency biogas production, studies in the field of high purity biogas production, as well as the design and construction of new bioreactors, are of interest. Janke et al. [10] 
investigated start-up phase strategies for semi-continuous AD of sugarcane filter cake mixed with bagasse as substrate and fresh cattle manure as inoculum at different concentrations. They also proposed the main parameter used for designing the AD on large-scale integrated to a sugarcane factory with the capacity to process 2 million tons of cane per year. They also explored macronutrient supplementation effect on conversion kinetics [13]. They found that adding supplementation of $\mathrm{N}_{2}$ in combination with phosphorus and sulfur resulted in faster degradation kinetics and significantly higher specific methane production. Carballa et al. [14] by using a continuous lab-scale reactor with a volume of $18 \mathrm{~L}$ correlated between the microbial community characteristics and reactor functionality. Their reactors operated in mesophilic $\left(34 \pm 2^{\circ} \mathrm{C}\right)$ and thermophilic $\left(53 \pm 2^{\circ} \mathrm{C}\right)$ conditions. They observed that an increase in the OLR caused the failure of the reactors, and they were stopped on day 72 . The effect of the different inocula on microbial communities was also investigated by Han et al. [15]. They observed that inoculum played an important role in shaping microbial communities. They also stated that the reactors with the same inoculum had different microbial communities and performances. Aquino et al. [16] introduced a structured-bed reactor as an alternative to conventional packed-bed reactors. They noted that the structured-bed reactor had a higher stability and degradation rate, even at higher OLR (18 $\mathrm{kg} \mathrm{COD} \mathrm{m}^{-3} \mathrm{~d}^{-}$ $\left.{ }^{1}\right)$ than the packed-bed reactor. By using a two-step process, Hatnan et al. [17] investigated biogas production in a pilot-scale AD. The acidogenic and methanogenic reactors were $5.13 \mathrm{~m}^{3}$ and $3.8 \mathrm{~m}^{3}$, respectively. They observed that methane concentration reached up to $70 \%$. Also, Fuess et al. [18] proposed that a fixed-film digester is an ideal reactor for the thermophilic two-step AD. They showed that their structured-bed reactor had a stable long-term operation, even for OLR values as high as $30 \mathrm{~kg}$ COD $\mathrm{m}^{-3} \mathrm{~d}^{-1}$. The improvement of methanogenic reactor stability was performed by Petracchini et al. [19]. They used a two-stage AD process, namely the sequential batch reactors and the methanogenic one, to produce biogas from food waste mixed with cow dung. Their results revealed that the biogas production by this process was stable (up to 80 days), high specific methane rate $\left(0.92 \mathrm{Nm}^{3} / \mathrm{kg}\right.$ TVS) and so pure (methane content $=0.85 \%$ ). Michalopoulos et al. [20] used six different types of waste with cheese whey as a substrate in a pilot-scale anaerobic baffled digester. Their substrate was made by mixing different animal wastes and cheese whey in different ratios. They deduced that the baffled reactor was very stable during the tests, providing biogas with an average methane composition of $65 \%$. Buitron et al. [21] inspected the effect of the OLR on an acidogenic followed by a methanogenic digestion process. They observed that the biogas production close to the theoretical value. They also achieved a high specific methane rate $\left(5.5 \mathrm{~m}^{3} \mathrm{CH}_{4} \mathrm{~m}^{-3} \mathrm{~d}^{-1}\right)$ and methane yield ( $\left.330 \mathrm{~L} \mathrm{CH}_{4} / \mathrm{kg} \mathrm{COD}\right)$ without the need for alkaline addition, which is desirable in terms of reactor stability. Over a period of one year, bio-methane production from a raw septic tank sludge in a $2 \mathrm{~m}^{3}$ pilot reactor was investigated, showing that methane concentration increased from $73.15-81.83 \%$ upon sonication pretreatment of the sludge [22]. Warade et al. [23] designed a portable bioreactor having 35 I working volume for producing biogas from Napier grass along with cow dung at an operating temperature range from 20 to $32^{\circ} \mathrm{C}$. They reported that the biogas production reached as high as $0.44 \mathrm{~m}^{3} / \mathrm{kg}$ VS. By using a compact plug flow reactor, Ramaswamy and Vemareddy [24] could produce biogas from cow dung and water in ratio of 1:10, which was enough to cook three meals a day for a family of six. Zeng et al. [25] constructed a self-flotation bioreactor and 
investigated its performance. They reported that COD removal efficiency for the self-flotation reactor was about $41 \%$ higher than that for an up-flow anaerobic sludge blanket (UASB).

To apply the produced biogas for commercial purposes, large-scale and continuous feeding bioreactors must be used. There are already considerable studies dealing with the problems of the biogas synthesis process and reactors.

Despite numerous studies carried out in the field of biogas, designing and building bioreactors that can produce methane continuously with high efficiency is a necessity. Therefore, in this study, to fill the gap in the literature, the design and construction of a pilot-scale continuous bioreactor to produce high-efficiency biogas from sugar beet waste have been investigated.

In this study, a continuous bioreactor was designed and constructed so that it could be easily start-up and controlled. Moreover, it was able to supply biogas with a constant volumetric flow and composition to consumers. For comparison, a set of batch reactors were also used at the same operating conditions. In batch reactors, biogas production was different in various days of reactor operating. Moreover, the percentage of methane content in the biogas is various for various days and with oscillation. Considering these two properties, it is seen that this system is not easy and, in some cases, impossible, to use for a consumer.

\section{Results And Discussion}

Three parameters, i.e., $\mathrm{pH}$, biogas volume, and methane composition were measured in this study. After collecting samples, methane percentage was analyzed, using Portable Gas Detector Smart Charger Type PGDC2 (gas analyzer, England), and its methane content was recorded. The maximum uncertainties of the measured parameters and the devices' precisions are listed in Table 1.

Table 1 Uncertainties and Precisions

\begin{tabular}{|lllllll|}
\hline Parameter/device & $\begin{array}{l}\text { Biogas } \\
\text { concentration }\end{array}$ & $\begin{array}{l}\text { Gas } \\
\text { volume }\end{array}$ & $\begin{array}{l}\mathrm{pH}- \\
\text { meter }\end{array}$ & $\begin{array}{l}\text { Gas } \\
\text { analyzer }\end{array}$ & VS & TS \\
\hline Uncertainty/Precision & $\pm 0.21 \%$ & $\pm 1 \%$ & \pm 0.01 & $\pm 0.10 \%$ & $0.30 \%$ & $1.16 \%$ \\
\hline
\end{tabular}

To ensure repeatability of the results, all measurements for reactors and matter specifications were repeated at least three times, and the reported data were the average values of three repetitions.

In our preliminary experiments, it was concluded that the suitable OLR was about $34.86 \mathrm{~g} \mathrm{VS} /$ day for biogas production in the continuous reactor. OLR values greater than or less than $34.86 \mathrm{~g} \mathrm{VS} /$ day lead to reduced biogas production efficiency. In the overload feeding system (i.e., for OLR value between 64 and $180 \mathrm{~g} \mathrm{VS}$ /day), due to the sharp drop in pH, biogas couldn't be produced. By adjusting the $\mathrm{pH}$, even for such a system, biogas production can be achieved, although the efficiency of the process was low. Therefore, the experiments were conducted based on OLR=34.86 g VS/day. Biogas was not produced in 
the reactor with high OLR, whilst $\mathrm{pH}$ adjustment made it possible to generate biogas. Methane content in biogas produced in the reactor with $\mathrm{pH}$ adjustment decreased below $30 \%$. Biogas production occurred with a long-time delay, so that after 18 days, very little or no biogas was produced. Table 2 shows the effect of hydraulic retention time (HRT) on specific biogas production (SBP). It has been seen that higher HRT was benefit to the biogas production and the TS and VS reduction; more time exposure of feeding material to microorganisms' activities improves the efficiency of the digestive process. These results are consistent with those reported in the literature [26-28]. Although better digestion occurred at the highest HRT, due to the small difference in the results of HRT 18 and 36 days, to reach the stable conditions faster, HRT=18 days was used in the experiments.

Table 2

Effect of HRT on anaerobic digestion process

\begin{tabular}{|llll|}
\hline HRT (day) & SBP $(\mathrm{mL} / \mathrm{g}$ VS) & VS reduction (\%) & TS reduction (\%) \\
\hline 9 to 11 & $287.7 \pm 2.99$ & 48.78 & 32.87 \\
\hline 18 to 20 & $411.2 \pm 4.3$ & 70.16 & 63.10 \\
\hline 36 to 40 & $452.65 \pm 4.71$ & 77.05 & 69.26 \\
\hline
\end{tabular}

$\mathrm{pH}$ drop is one of the most important problems of the anaerobic digestion process; it may disrupt the methane production process and result in less biogas production [9]. $\mathrm{pH}$ drop was observed in all batch and continuous reactors in the early days of the reaction. This happened as a result of a conversion of organic matter into volatile fatty acids (VFA). According to previous studies, the appropriate $\mathrm{pH}$ for biogas reactors is seven $[9,12]$, so the $\mathrm{pH}$ of all reactors was adjusted to values of 7 in the initial 4 days of the test, as is clearly seen in Fig. 1. In all samples, a rapid drop in pH over the 4 days of the process was seen, and from the 4 th day until the end of the process, $\mathrm{pH}$ was in the optimal range.

As shown in Fig. 1 (dotted line), a very high pH drop was observed during the first four days. This drop was due to the severe transformation of the substrate into VFA. While reactors with adjusted $\mathrm{pH}$ could recover and return to the optimum range for methane activity, the ones with unadjusted $\mathrm{pH}$ failed to produce good biogas.

The $\mathrm{pH}$ value on the first 4 days was within in acidic range, which was $6.17,6.41,6.6$, and 6.75 , from the first to the fourth day, respectively; then, it was adjusted to 7 by adding 1 molar $\mathrm{NaOH}$ solution. From the 4th day onward, $\mathrm{pH}$ was almost neutral, and in the next few days, $\mathrm{pH}$ gradually grew higher than 7 . The highest $\mathrm{pH}$ was recorded on day 17 with 7.79 in the continuous reactor, while it was 7.85 on days 22 to 24 in the batch ones. The reported data for the batch reactor are the average results of the batch reactors, at least three reactors.

Figure 2 shows the methane content of the biogas produced in the batch and continuous reactors. One of the most prominent advantages of the designed reactor is the production of the biogas in constant volume and composition until operation days. 
According to Fig. 2, in the batch reactor, the composition of methane varies from day to day, whereas in the designed continuous reactor, the methane composition was increasing up to the thirteenth day and then became stable, with a fixed output of nearly $53 \%$. The biogas output of the continuous bioreactor on the eighteenth day after launch is, in fact, a mixture of gas produced from the first to the eighteenth day. After 18 days of operation, the continuous bioreactor was filled; on the nineteenth day of operation, the residual matter as waste was removed the continuous bioreactor from the waste outlet conduit. The biogas contained about $53 \%$ methane and the rest of the biogas approximately could be considered $\mathrm{CO}_{2}$. By using additional operations such as $\mathrm{CO}_{2}$ absorption, the purity of produced biogas could have been increased. The highest menthane content reached $62 \%$ in the batch reactor. It seems that in the batch reactor, the value of stirring was greater than the continuous reactor, spreading microorganisms throughout the substrate and producing more pure biogas $\left(62 \% \mathrm{CH}_{4}\right)$.

As seen in Fig. 2, the methane gas content for batch reactors is a function of the test time. In the first 5 days, the methane content of the biogas output was low with an average of $31.8 \%$. On the 6 th day, the methane content reached $55 \%$, and since then has a production fluctuation on different days, with the highest percentage of production on the 8 th day being $62 \%$, and from the 10 th day, it was decreasing until the 18th day which was $41 \%$.

The amount of biogas production per day for both continuous and batch reactors is shown in Fig. 3 .

As seen in Fig. 3, the daily volume of biogas production in the batch reactor was irregular. On the beginning days and last days, the volume of production was low and on the middle days, there was no constant trend. Given about $400 \mathrm{~mL}$ volume of raw material for the batch reactor, the highest volume of biogas production was on the 7th day, producing $226.6 \mathrm{~mL}$ of biogas. From the 14th day onward, the biogas production process was decreasing, and the biogas production reached $17.6 \mathrm{~mL}$ on the final day (21st day). Whereas in the designed continuous reactor, with the addition of about 1.5 liters of raw material per day to the reactor, the value of biogas production increased daily, and after the 18th day the process was stable reaching about $24170 \mathrm{~mL}(38.52 \mathrm{~mL} / \mathrm{g}$ VS loaded within 18 days at steady state condition).

A comparison of the cumulative volume of biogas production for the continuous reactor and batch one is shown in Fig. 4.

As seen in Fig. 4, the cumulative volume of biogas produced in the batch reactor was reached constant volume after 21st day of operation. The volume of production for the batch reactor reaches $2835 \mathrm{~mL}$ (244.19 mL/ g VS), and then it was almost constant, reaching $2916 \mathrm{~mL}(251.16 \mathrm{~mL} / \mathrm{g} \mathrm{VS})$ on the $21 \mathrm{st}$ day. While the cumulative biogas production in the continuous reactor was always ascending manner and it was reached $330.5 \mathrm{~L}$ on the 21 st day of operation. After 18 days of launch, biogas production reached $258 \mathrm{~L}(411.2 \mathrm{~mL} / \mathrm{g}$ VS loaded within 18 days) at steady state condition.

The biogas production and methane content in this study were compared with the results reported in the literatures, as listed in Table 3. Although biogas production depends on the substrate and operating 
conditions such as T, OLR, and HRT, methane content and biogas production in this work are more than or within the range of the results of the other researches which are tabulated.

Table 3

Comparison between the experimental data and the literatures data

\begin{tabular}{|c|c|c|c|c|}
\hline Study & $\begin{array}{l}\text { Biogas } \\
\text { production } \\
\text { (methane } \\
\text { content) }\end{array}$ & Substrate & $\begin{array}{l}\text { Bioreactor } \\
\text { Volume }\left(\mathrm{m}^{3}\right) \\
\text { (HRT in day) }\end{array}$ & OLR \\
\hline This work & $\begin{array}{l}411.2 \mathrm{~mL} / \mathrm{g} \\
\text { VS } \\
(53 \%)\end{array}$ & Sugar beet waste & $\begin{array}{l}0.022 \\
(18)\end{array}$ & $\begin{array}{l}34.86 \\
\text { gVS/day }\end{array}$ \\
\hline $\begin{array}{l}\text { Ihara et al. } \\
\text { [27] }\end{array}$ & $\begin{array}{l}\approx 350 \mathrm{~mL} / \mathrm{g} \\
\mathrm{VS} \\
(58 \%)\end{array}$ & $\begin{array}{l}\text { Liquid dairy manure with } \\
\text { food waste }\end{array}$ & $\begin{array}{l}8 \\
(40-50)\end{array}$ & $\begin{array}{l}2.5-5 \mathrm{~kg} \\
\mathrm{VS} / \mathrm{m} 3 / \mathrm{d}\end{array}$ \\
\hline $\begin{array}{l}\text { Abbas et al. } \\
\text { [29] }\end{array}$ & $\begin{array}{l}380-510 \\
\mathrm{~mL} / \mathrm{g} \text { VS } \\
(63.5-66.4 \%)\end{array}$ & Animal manure & $\begin{array}{l}2.15 \\
(30)\end{array}$ & $\begin{array}{l}20-40 \\
\mathrm{~kg} / \mathrm{day}\end{array}$ \\
\hline $\begin{array}{l}\text { Kafle and } \\
\text { Kim [30] }\end{array}$ & $\begin{array}{l}276 \mathrm{~mL} / \mathrm{g} \\
\text { TCOD } \\
(54.6 \%)\end{array}$ & $\begin{array}{l}\text { Apple waste with swine } \\
\text { manure }\end{array}$ & $\begin{array}{l}0.0045 \\
(30)\end{array}$ & $5 \mathrm{~g} \mathrm{VS} / \mathrm{L}$ \\
\hline Li et al. [26] & $\begin{array}{l}223 \mathrm{~mL} / \mathrm{g} \text { VS } \\
(50.2 \%)\end{array}$ & $\begin{array}{l}\text { Chicken manure and corn } \\
\text { stover }\end{array}$ & $\begin{array}{l}0.009 \\
(22.5)\end{array}$ & $4 \mathrm{~g} \mathrm{VS} / \mathrm{L}$ \\
\hline
\end{tabular}

\section{Conclusion}

In this study, the novel portable continuous reactor for biogas production from sugar beet waste was designed and constructed in such a way that it could meet the constant and uniform flow of biogas needed by consumers. To analyze the performance of the continuous reactor, the results of its performance were compared with that of the batch reactors. The volume and composition percentage of the biogas produced in batch reactors is fluctuating. This fluctuation makes the use of biogas difficult and in some cases impossible. For the biogas to be practically useable, it must be stored which results in high storage cost and expense of purchasing tanks, or the biogas must remain in the reactor, which causes an increase in the pressure inside the reactors and lead to production problems. The minimum and the maximum volume of produced biogas in the batch reactor was $17.6 \mathrm{ml}$ on the $21 \mathrm{st}$ day and $226.6 \mathrm{ml}$ on the 7th day, respectively. Furthermore, the highest percentage of methane was on the 8th day and equal to $62 \%$, while in the continuous reactor, biogas with a constant volumetric flow rate was achieved after 18 days of operation $(24170 \mathrm{~mL} /$ day $)$. The percentage of methane in the biogas produced by this machine in a stable situation was about $53 \%$. The methane percentage in the biogas was low, one 
of the reasons being that at the reactor output, a mixture of gases from the 1st to 18th days exists. A high percentage of this mixture was carbon dioxide. Methane percentage could be increased to a significant degree through dehumidification and removal of carbon dioxide. According to the results, the reactor designed makes the biogas production process more manageable. Besides the production of the cumulative volume of biogas (on the 18th day was about $411.2 \mathrm{~mL} / \mathrm{g}$ VS per day) and constant methane percentage (from 10th day after about $53 \%$ ) was achieved. As a result, the biogas produced is consumed daily, and a certain amount of gas is available every day. Since the percentage of gas produced is constant, it is possible to adjust the gas appliances with this amount of methane. From the comparison of the results of this reactor with previous ones, one can conclude that one way of producing and using biogas on an industrial and semi-industrial scale is to employ such simple, inexpensive and, flexible reactors.

\section{Methods}

\section{Experimental Setup and procedure}

In this study, a continuous portable bioreactor, as seen in Figure 5, was used to produce biogas from organic matter. The methanogenic reactor had two compartments, one for digestion and the other for collecting the produced biogas from the reaction, connected by gas-in-pipe interconnections. A screw barrel was used for pushing the raw material forward.

The body of the reactor was made of polyethylene with an outside diameter of $160 \mathrm{~mm}$ and an inner diameter of $147 \mathrm{~mm}$. The length of the reactor was $1.43 \mathrm{~m}$ with a working volume of $23 \mathrm{~L}$. As polyethylene is good thermal insulation, it prevents heat dissipation inside the reactor. The flexible polyethylene tube has also a flexible manner that allows the screw barrel to move in it freely. The raw material inlet gate had a $110 \mathrm{~mm}$ valve opening, which is closed after the daily entry of the materials and sealed with an 0-ring.

The screw barrel was made of steel, the shaft of which was a $25 \mathrm{~mm}$ tube which was welded together. The screw barrel was connected to a 32 nut, so that it could be moved to the desired direction with a wrench.

For heating of the reactor, a 2000-Watt/220-Volt industrial element was used. An industrial thermostat was used to control the temperature, so that the temperature can be adjusted at the desired value. For this purpose, the reactor wall was perforated and the tip of the thermocouple was inserted into the reactor in contact with the material.

The biogas collecting tank is a UPVC tube with $110 \mathrm{~mm}$ diameter, blocked on one end with a bung, and on the other end, using UPVC fittings, it is connected to the gas collecting tank, forming a complete tank. Four valves are used to exhaust biogas from the pipe. The valves are made of polyethylene and connected to the gas collecting tank through some hoses. 
According to the results obtained from our previous work [9], the maximum change in $\mathrm{pH}$ was in the initial 4 days and then remains within a constant range. Therefore, the raw material was prepared in 1.5-liter acidogenic reservoirs daily until the fourth day, acidity was measured every day and adjusted to 7 . On the fourth day, the raw material was injected into the continuous methanogenic reactor and $\mathrm{pH}$ adjustment was stopped. Loading the material was repeated for 18 days until the reactor was stable.

\section{Substrate and inoculum}

Since sugar beet was not available in different months of the year, it was stored at $4{ }^{\circ} \mathrm{C}$ temperature so that it could be used during the whole year [9]. The sugar beets which were used for the experiments had been stored for 3 to 7 weeks. Storing the beets had no significant effect on their physicochemical properties and/or the ability of biogas production. Due to the existence of clay on the surface of the beets, they were washed, as done in sugar factories, and their top and bottom were cut. Then the beets were grated before loading into the reactor.

Anaerobic sludge was supplied from an industrial wastewater treatment plant in Quchan $[9,12]$. The physic-chemical characteristics of substrate and inoculum are mentioned in Table 4. To measure the total solids (TS) of the inoculum, a $10 \mathrm{ml}$ sample was dried at $105^{\circ} \mathrm{C}$ for 12 hours. Then, the dried sample was weighted. The sugar beet TS similarly was measured for a $10 \mathrm{~g}$ sample. The dried samples, i.e., inoculum and substrate, were put in a furnace at $550^{\circ} \mathrm{C}$ for $30 \mathrm{~min}$ to obtain the inorganic ash (fixed solid). Volatile solid is equal to a loss of sample mass. Finally, the samples' VS percent was calculated by dividing the mass of VS to dry matter and represented in Table 4.

Table 4- The physic-chemical characteristics of substrate and inoculum

\begin{tabular}{|llll|}
\hline & TS & VS & VS (\%) \\
SBW & $435.80(\mathrm{~g} / \mathrm{kg})$ & $387.12(\mathrm{~g} / \mathrm{kg})$ & 88.83 \\
\hline Anaerobic Sludge & $34275(\mathrm{mg} / \mathrm{L})$ & $19820.90(\mathrm{mg} / \mathrm{L})$ & 57.83 \\
\hline
\end{tabular}

\section{Substrate and inoculum ratio (S/I)}

For the continuous reactor, activated sludge and sugar beet waste were used as an inoculum and a substrate, respectively. The most effective $S / I$ ratio (i.e., 0.5 to 1 ) was used for continuous testing [9]. For comparison of batch and continuous process efficiency and behavior, a set of batch reactors, similar to what was reported in reference [9], was provided. The results of the mentioned batch reactors were used to evaluate and compare with that of the continuous reactor.

\section{Declarations}

- Ethics approval and consent to participate

Not applicable 
- Consent for publication

Not applicable

\section{- Availability of data and materials}

All the data analyzed are included in the published articles presented into the references part.

\section{- Competing interests}

The authors declare that they have no competing interests.

\section{- Funding}

This research did not receive any specific grant from funding agencies in the public, commercial, or notfor-profit sectors.

\section{- Authors' contributions}

All authors contributed to the study conception and design.

MAkh: Setup design and construction, material preparation, data collection, experiment operation, validation, writing (original) draft.

HB: Methodology, conceptualization, experiment design and operation, validation, visualization, data curation, writing (review), and editing.

MK: Methodology, conceptualization, setup design and construction, experiment design and operation, validation, data curation.

All authors read and approved the final manuscript.

\section{- Acknowledgements}

Not applicable

\section{References}

1. Beiki H, Soukhtanlou E: Improvement of salt gradient solar ponds' performance using nanoparticles inside the storage layer. Applied Nanoscience 2019, 9(2):243-254.

2. Peng P, Lan Y, Liang L, Jia K: Membranes for bioethanol production by pervaporation. Biotechnology for Biofuels 2021, 14(1):10.

3. Gabbanelli N, Erbetta E, Sanz Smachetti ME, Lorenzo M, Talia PM, Ramírez I, Vera M, Durruty I, Pontaroli AC, Echarte MM: Towards an ideotype for food-fuel dual-purpose wheat in Argentina with focus on biogas production. Biotechnology for Biofuels 2021, 14(1):85. 
4. Beiki $\mathrm{H}$, Soukhtanlou E: Determination of optimum insulation thicknesses for salinity gradient solar pond's bottom wall under different climate conditions. SN Applied Sciences 2020, 2(7):1284.

5. Bala R, Mondal MK: Study of biological and thermo-chemical pretreatment of organic fraction of municipal solid waste for enhanced biogas yield. Environmental Science and Pollution Research 2020, 27(22):27293-27304.

6. Barrios JA, Cano A, Rivera FF, Cisneros ME, Durán U: Efficiency of integrated electrooxidation and anaerobic digestion of waste activated sludge. Biotechnology for Biofuels 2021, 14(1):81.

7. Ali SS, Al-Tohamy R, Koutra E, Kornaros M, Khalil M, Elsamahy T, El-Shetehy M, Sun J: Coupling azo dye degradation and biodiesel production by manganese-dependent peroxidase producing oleaginous yeasts isolated from wood-feeding termite gut symbionts. Biotechnology for Biofuels 2021, 14(1):61.

8. Beiki H, Dadvar M, Halladj R: Pore network model for catalytic dehydration of methanol at particle level. AlChE Journal 2009, 55(2):442-449.

9. Keramati $\mathrm{M}$, Beiki $\mathrm{H}$ : The effect of $\mathrm{pH}$ adjustment together with different substrate to inoculum ratios on biogas production from sugar beet wastes in an anaerobic digester. Journal of Energy Management and Technology 2017, 1(2):6-11.

10. Janke L, Leite AF, Nikolausz M, Radetski CM, Nelles M, Stinner W: Comparison of start-up strategies and process performance during semi-continuous anaerobic digestion of sugarcane filter cake codigested with bagasse. Waste Management 2016, 48:199-208.

11. Treichel H, Fongaro G: Improving Biogas Production: Technological Challenges, Alternative Sources, Future Developments, vol. 9: Springer; 2019.

12. Beiki H, Keramati M: Improvement of Methane Production from Sugar Beet Wastes Using TiO2 and Fe304 Nanoparticles and Chitosan Micropowder Additives. Applied Biochemistry and Biotechnology 2019, 189(1):13-25.

13. Janke L, Weinrich S, Leite AF, Schüch A, Nikolausz M, Nelles M, Stinner W: Optimization of semicontinuous anaerobic digestion of sugarcane straw co-digested with filter cake: Effects of macronutrients supplementation on conversion kinetics. Bioresource Technology 2017, 245:35-43.

14. Carballa M, Smits M, Etchebehere $C$, Boon N, Verstraete W: Correlations between molecular and operational parameters in continuous lab-scale anaerobic reactors. Applied Microbiology and Biotechnology 2011, 89(2):303-314.

15. Han S, Liu Y, Zhang S, Luo G: Reactor performances and microbial communities of biogas reactors: effects of inoculum sources. Applied Microbiology and Biotechnology 2016, 100(2):987-995.

16. de Aquino S, Fuess LT, Pires EC: Media arrangement impacts cell growth in anaerobic fixed-bed reactors treating sugarcane vinasse: Structured vs. randomic biomass immobilization. Bioresource Technology 2017, 235:219-228.

17. Hutnan M, Drtil M, Derco J, Mrafkova L, Hornak M, Mico S: Two-step pilot-scale anaerobic treatment of sugar beet pulp. Polish Journal of Environmental Studies 2001, 10(4):237-244. 
18. Fuess LT, Kiyuna LSM, Ferraz ADN, Persinoti GF, Squina FM, Garcia ML, Zaiat M: Thermophilic twophase anaerobic digestion using an innovative fixed-bed reactor for enhanced organic matter removal and bioenergy recovery from sugarcane vinasse. Applied Energy 2017, 189:480-491.

19. Petracchini F, Liotta F, Paolini V, Perilli M, Cerioni D, Gallucci F, Carnevale M, Bencini A: A novel pilot scale multistage semidry anaerobic digestion reactor to treat food waste and cow manure. International Journal of Environmental Science and Technology 2018, 15(9):1999-2008.

20. Michalopoulos I, Mathioudakis D, Premetis I, Michalakidi S, Papadopoulou K, Lyberatos G: Anaerobic Co-digestion in a Pilot-Scale Periodic Anaerobic Baffled Reactor (PABR) and Composting of Animal By-Products and Whey. Waste and Biomass Valorization 2019, 10(6):1469-1479.

21. Buitrón G, Martínez-Valdez FJ, Ojeda F: Biogas Production from a Highly Organic Loaded Winery Effluent Through a Two-Stage Process. BioEnergy Research 2019.

22. Chatterjee P, Ghangrekar MM, Rao S: Biogas Production from Partially Digested Septic Tank Sludge and its Kinetics. Waste and Biomass Valorization 2019, 10(2):387-398.

23. Warade H, Daryapurkar R, Nagarnaik PB: Assessment of Biogas Production from Energy Crop Using Animal Manure as Co-substrate Through Portable Reactor. In: Smart Technologies for Energy, Environment and Sustainable Development: 2019// 2019; Singapore. Springer Singapore: 165-174.

24. Ramaswamy J, Siddareddy Vemareddy P: Production of biogas using small-scale plug flow reactor and sizing calculation for biodegradable solid waste. Renewables: Wind, Water, and Solar 2015, 2(1):6.

25. Zeng Z, Zheng P, Zhang M, Ghulam A: Performance and working mechanism of a novel anaerobic self-flotation reactor for treating wastewater with high suspended solids. Environmental Science and Pollution Research 2019.

26. Li Y, Zhang R, He Y, Zhang C, Liu X, Chen C, Liu G: Anaerobic co-digestion of chicken manure and corn stover in batch and continuously stirred tank reactor (CSTR). Bioresource technology 2014, 156:342-347.

27. Ihara I, Yano K, Andriamanohiarisoamanana FJ, Yoshida G, Yuge T, Yuge T, Tangtaweewipat S, Umetsu K: Field testing of a small-scale anaerobic digester with liquid dairy manure and other organic wastes at an urban dairy farm. Journal of Material Cycles and Waste Management 2020, 22(5):1382-1389.

28. Dareioti MA, Kornaros M: Effect of hydraulic retention time (HRT) on the anaerobic co-digestion of agro-industrial wastes in a two-stage CSTR system. Bioresource technology 2014, 167:407-415.

29. Abbas I, Liu J, Noor RS, Faheem M, Farhan M, Ameen M, Shaikh SA: Development and performance evaluation of small size household portable biogas plant for domestic use. Biomass Conversion and Biorefinery 2020:1-13.

30. Kafle GK, Kim SH: Anaerobic treatment of apple waste with swine manure for biogas production: batch and continuous operation. Applied Energy 2013, 103:61-72.

\section{Figures}




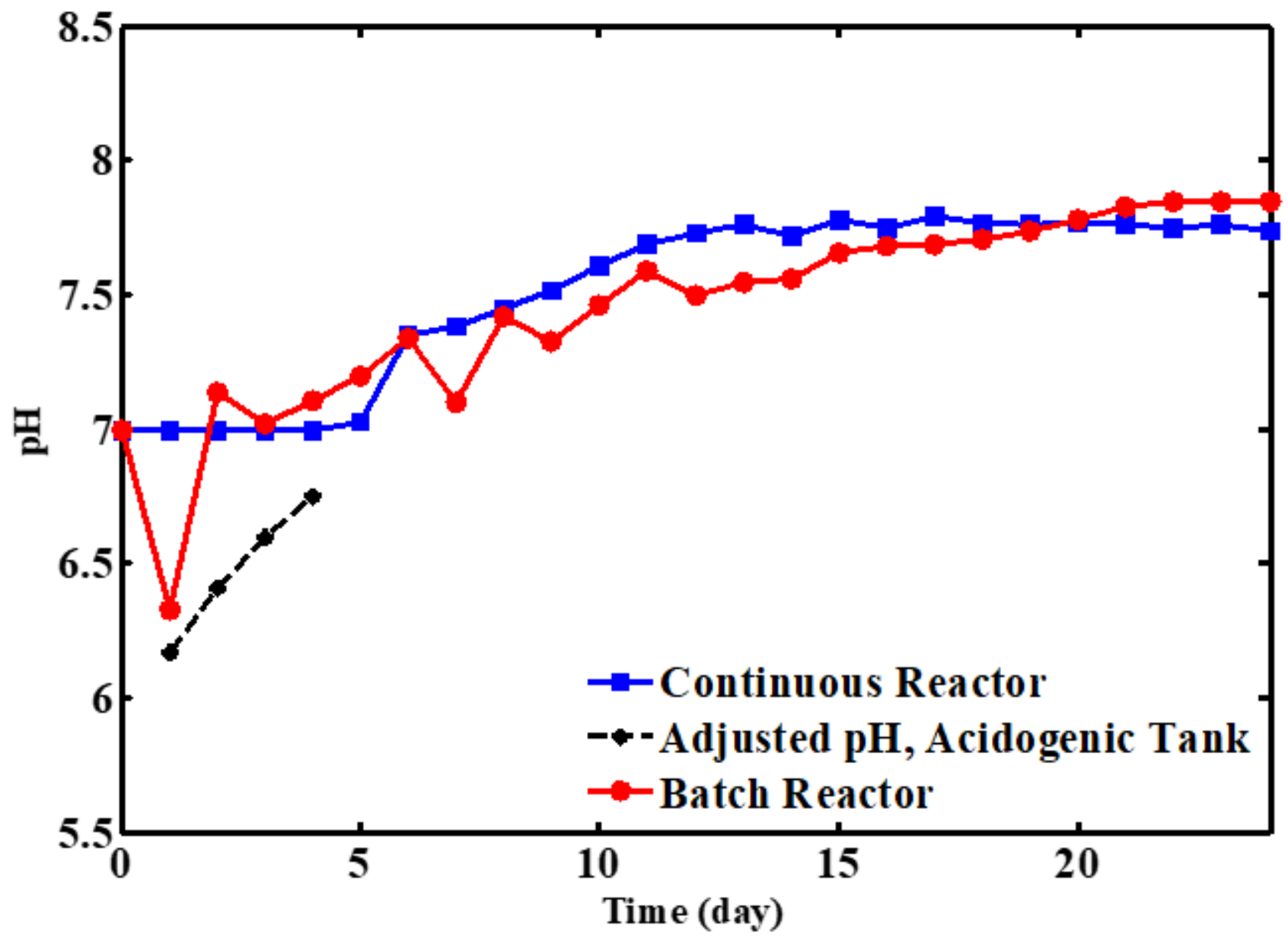

Figure 1

$\mathrm{pH}$ changes for sludge and sugar beet mixture with a ratio of $\mathrm{S} / \mathrm{I}=0.5: 1$ 


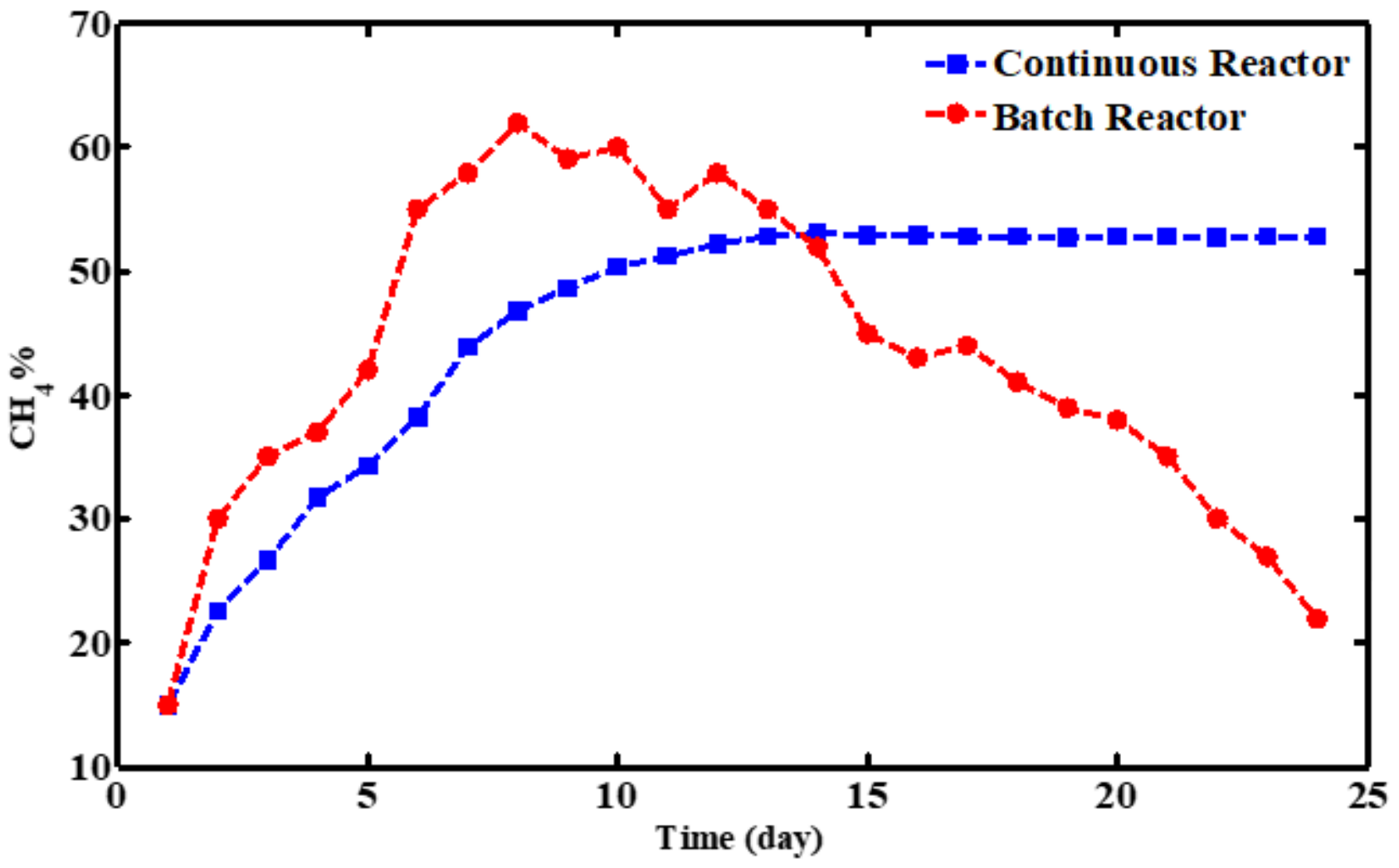

Figure 2

The percentage of methane in the biogas for continuous and batch reactors in the beet and sludge system 


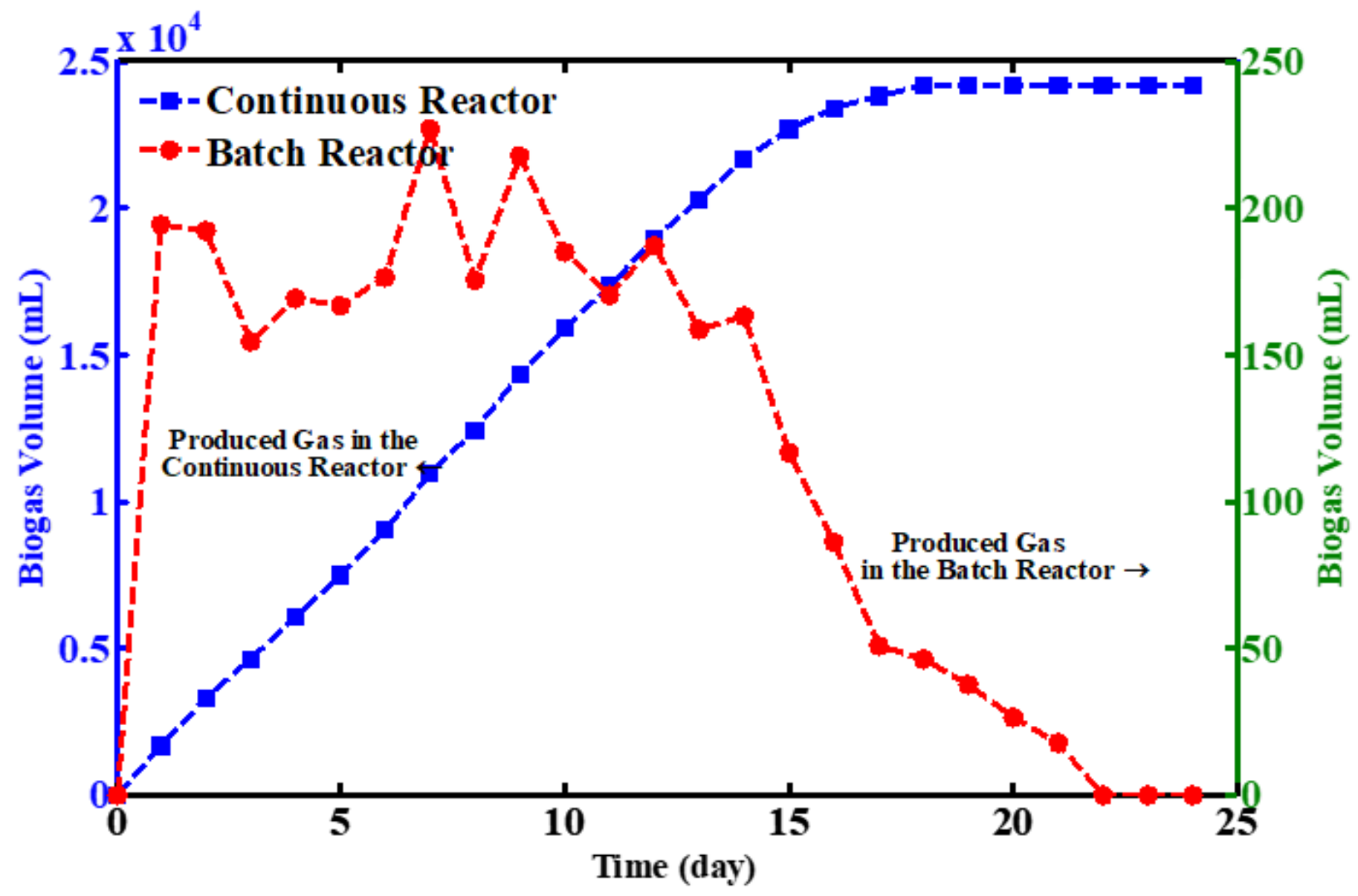

Figure 3

The daily biogas volume produced in the batch and continuous reactors 


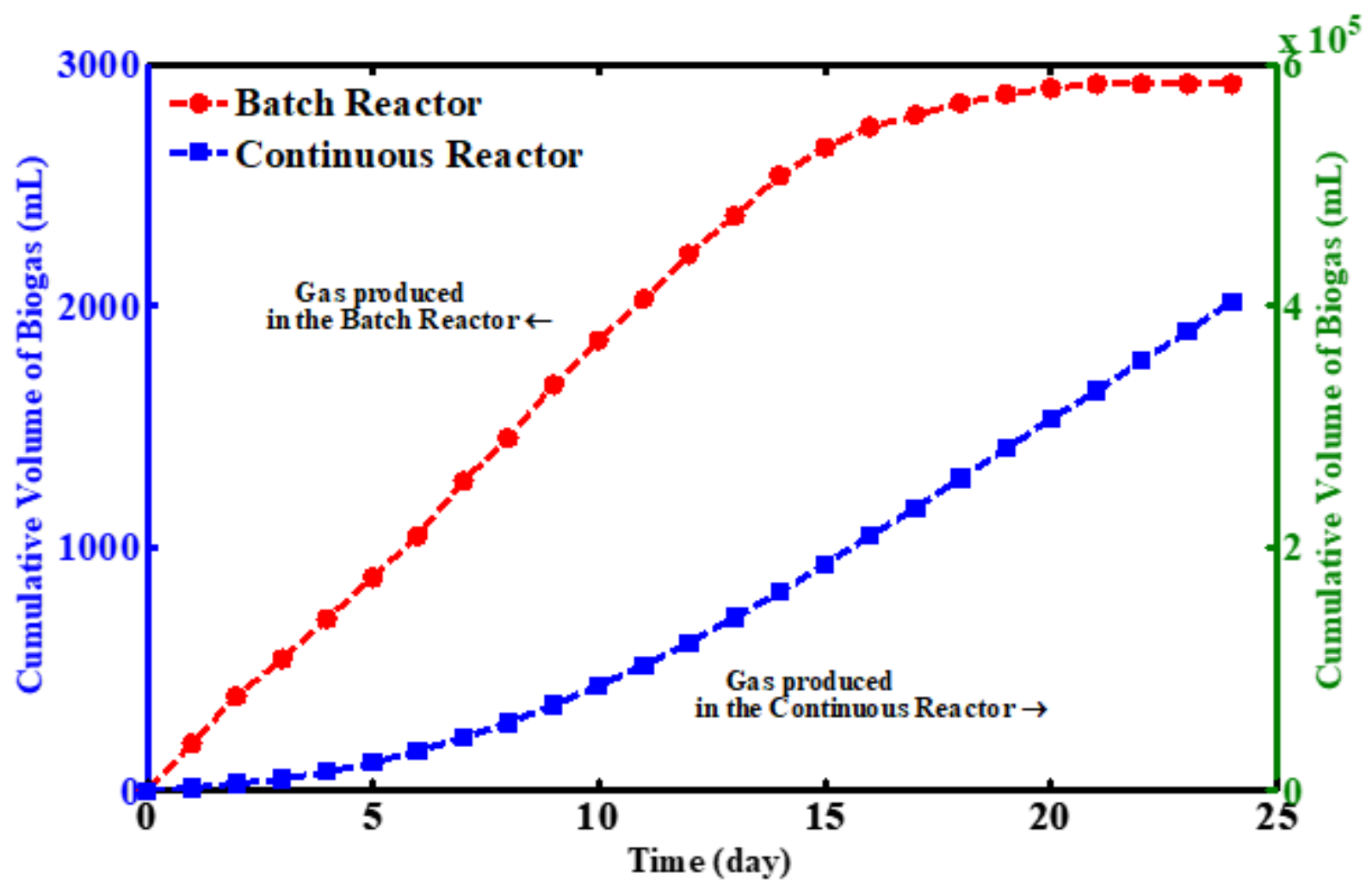

Figure 4

Cumulative volume of biogas production for the continuous and batch reactors 
a)

\section{Feed inlet gate}

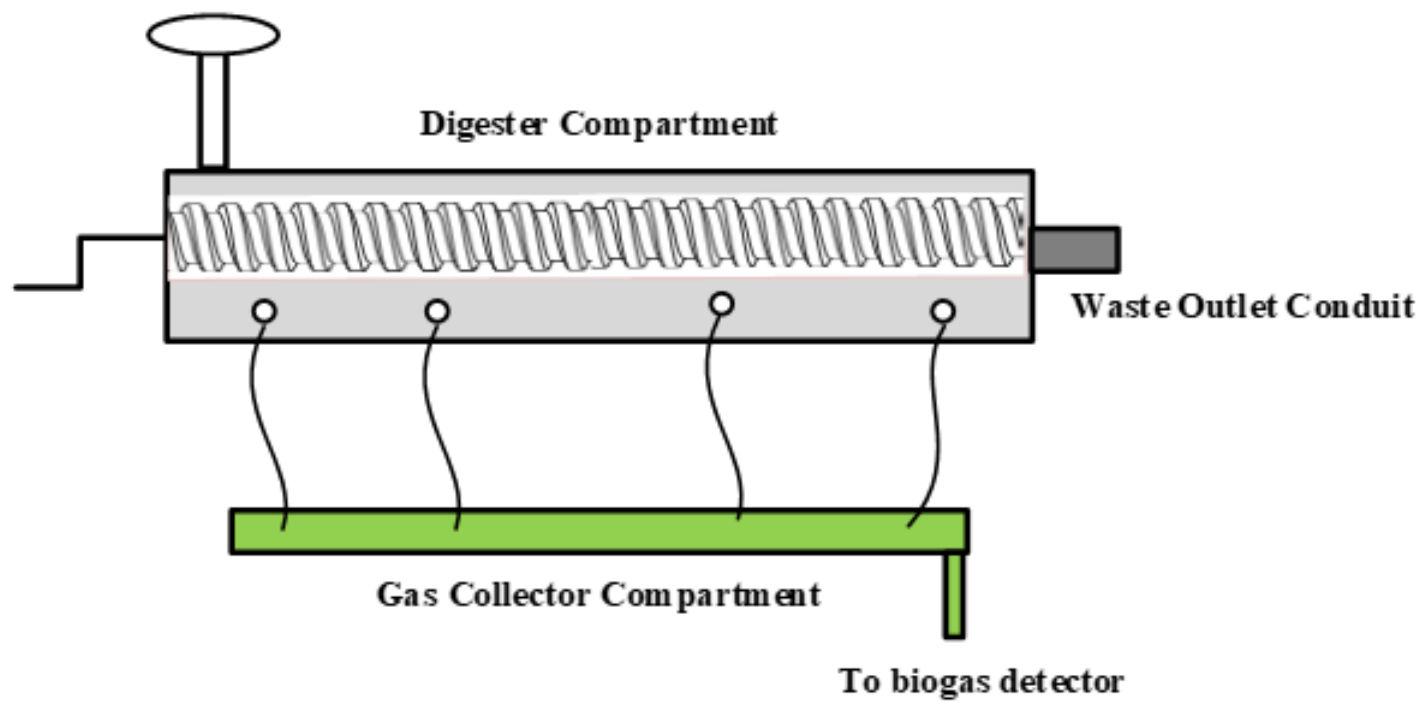

b)

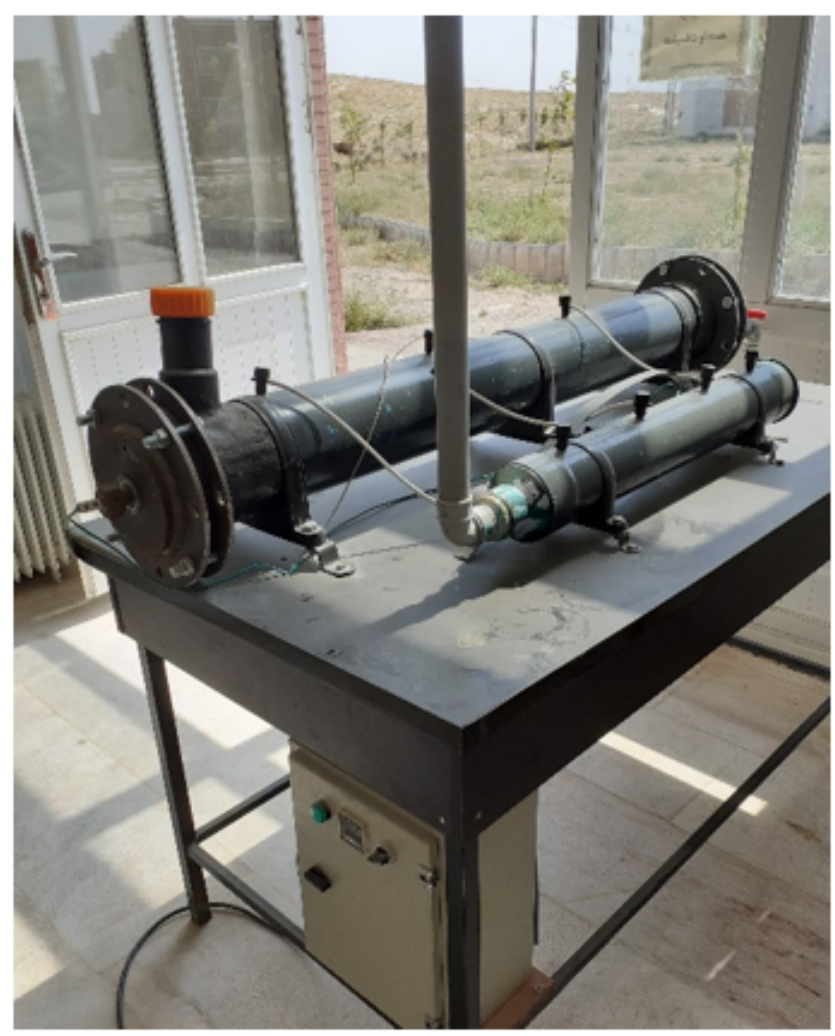

Figure 5

a) Schematic diagram of setup, b) Photograph of the portable continuous bioreactor 